PACS: 42.62Cf:42.65

UDC: 53.043:54.01

\title{
Some problems of modeling laser-induced filaments
}

\author{
P. P. Trokhimchuck \\ Lesya Ukrayinka East European National University, Voly av. 13, 43025, Lutsk, Ukraine \\ trope1650@gmail.com
}

ORCID: 0000-0003-2737-0506

DOI:10.26565/2222-5617-2020-32-06

Experimental data of formation laser-induced filaments in various media (potassium chloride, water, air and silicon carbide) are represented. These phenomena are analyzed as processes of Nonlinear and Relaxed Optics. Problems of modeling the creation the volume laser-induced filaments are investigated. Comparative analysis of plasma, nonlinear optical, diffractive and interference phenomena (including diffractive stratification), shocking processes (including Cherenkov radiation) and physical-chemical processes (including cascade model of excitation the proper chemical bonds in the regime of saturation the excitation), methods and models are represented and discussed. The optical breakdown for various matters has various natures: from shock ionization of gas to disruption of all chemical bonds for solid in the region of interaction light and matter or from nonequilibrium radiated processes in gas and liquid to irreversible phase transformations in solid. For diffraction stratification the modified models of Rayleygh rings was used. We show that this model allow to explain the experimental data for silicon carbide more effectively as Lugovoy-Prokhorov theory of moving foci. Modified Niels and Aage Bohrs models (microscopic) and Golub model (macroscopic) of Cherenkov radiation were used for the explanation of generation continuous radiation. Diffraction stratification shows the surface conic nature of Cherenkov radiation. It was show that physical-chemical method of estimations of corresponding processes is more general as electromagnetic (Kerr media) and one allow explain basic terms of resulting chain process with united point of view. Modified I. Frank model of interference the Cherenkov radiation was used for the explanation laser-induced optical breakdown in silicon carbide. Modified Rayleygh model and methods of continuum mechanics was created and used for the estimation sizes and form of observing nanovoids of silicon carbide. In whole the represented models allow to explain the corresponding chain more fuller and really as other models because one take into account of nonlinear optical transformation of primary laser radiation.

Keywords: laser irradiation, filaments, Rayleygh, Bohr, Frank, Cherenkov radiation, diffractive stratification, Relaxed Optics.

\section{Деякі проблеми моделювання лазерно-індукованих філаментів}

\author{
П. П. Трохимчук \\ Східноєвропейський національний університет імені Лесі Украӥнки, просп. Волі, 13, 43025, Луцьк, Украӥна
}

Представлені експериментальні дані формування лазерно-індукованих філаментів в різних середовищах (хлорид калію, вода, повітря і карбід кремнію). Ці явища аналізуються як процеси нелінійної та релаксаційної оптики. Досліджено проблеми моделювання створення об'ємних лазерно-індукованих філаментів. Порівняльний аналіз плазмових, нелінійнооптичних, дифракційних та інтерференційних явищ (включаючи дифракційне розшарування), ударних процесів (включаючи черенковське випромінювання) і фізико-хімічних процесів (включаючи каскадну модель збудження хімічних зв'язків в режимі насичення збудження), методи і моделі представлені та обговорені. Показано, що оптичний пробій для різних речовин має різну природу: від ударної іонізації газу до руйнування всіх хімічних зв'язків для твердого тіла в області взаємодії світла і речовини або від нерівноважних випромінювальних процесів для газів і рідин до незворотних фазових перетворень в твердому тілі. Для дифракційного розшарування використовувається модифікована модель кілець Релея. Показано, що ця модель дозволяє більш ефективно пояснити експериментальні дані для карбіду кремнію в порівнянні $з$ теорією рухомих фокусів Лугового-Прохорова. Для пояснення генерації неперервного випромінювання використовувалися модифіковані моделі Нільса і Оге Бора (мікроскопічні) і модель Голуба (макроскопічна) черенковського випромінювання. Дифракційне розшарування підтверджує поверхневу конічну природу черенковського випромінювання. Показано, що фізико-хімічний метод оцінки відповідних процесів є більш загальним, ніж електромагнітний (керрівські середовища), і дозволяє з єдиної точки зору пояснити основні особливості ланцюгового процесу. Модифікована модель І. Франка для інтерференції черенковського випромінювання використовувалася для пояснення лазерного оптичного пробою в карбіді кремнію. Модифікована модель Релея і методи механіки суцільних середовищ були створені та використані для оцінки розмірів і форми спостережуваних нановоідов карбіду кремнію. В цілому представлені моделі дозволяють більш повно та адекватно пояснити відповідний ланцюжок явищ в порівнянні з іншими моделями, оскільки враховують нелінійно-оптичне перетворення первинного лазерного випромінювання.

Ключові слова: лазерне опромінення, філаменти, Релей, Бор, Франк, черенковське випромінювання, дифракційне розшарування, релаксаційна оптика.

(C) Trokhimchuck P. P., 2020 


\title{
Некоторые проблемы моделирования лазерно-индуцированных филаментов
}

\author{
П. П. Трохимчук \\ Восточноевропейский национальный университет имени Леси Украинки, просп. Воли, 13, 43025, Луик, Украина
}

Представлены экспериментальные данные формирования лазерно-индуцированных филаментов в различных средах (хлорид калия, вода, воздух и карбид кремния). Эти явления анализируются как процессы нелинейной и релаксационной оптики. Исследованы проблемы моделирования создания объемных лазерно-индуцированных филаментов. Сравнительный анализ плазменных, нелинейно-оптических, дифракционных и интерференционных явлений (включая дифракционное расслоение), ударных процессов (включая черенковское излучение) и физико-химических процессов (включая каскадную модель возбуждения химических связей в режиме насыщения возбуждения), методы и модели представлены и обсуждены. Показано, что оптический пробой для различных веществ имеет различную природу: от ударной ионизации газа до разрушения всех химических связей для твердого тела в области взаимодействия света и вещества или от неравновесных излучаемых процессов для газов и жидкостей до необратимых фазовых превращений в твердом теле. Для дифракционного расслоения использовалась модифицированная модель колец Рэлея. Показано, что эта модель позволяет более эффективно объяснить экспериментальные данные для карбида кремния по сравнению с теорией движущихся фокусов ЛуговогоПрохорова. Для объяснения генерации непрерывного излучения использовались модифицированные модели Нильса и Оге Бора (микроскопические) и модель Голуба (макроскопическае) черенковского излучения. Дифракционное расслоение подтверждает поверхностную коническую природу черенковского излучения. Показано, что физико-химический метод оценки соответствующих процессов является более общим, чем электромагнитный (керровские среды), и позволяет с единой точки зрения объяснить основные особенности возникающего цепного процесса. Модифицированная модель И. Франка для черенковского излучения использовалась для объяснения лазерного оптического пробоя в карбиде кремния. Модифицированная модель Рэлея и методы механики сплошных сред были созданы и использованы для оценки размеров и формы наблюдаемых нановоидов карбида кремния. В целом представленные модели позволяют более полно и реально объяснить соответствующую цепочку явлений по сравнению с другими моделями, поскольку учитывают нелинейнооптическое преобразование первичного лазерного излучения.

Ключевые слова: лазерное облучение, филаменты, Релей, Бор, Франк, черенковское излучение, дифракционное расслоение, релаксационная оптика.

\section{Introduction}

Problems of modeling the creation the volume laserinduced structures (filaments) are very interesting. These structures have various sizes: from micrometetrs in solid [1-5] to few hundred meters in air [1-3]. In whole, we can have various processes and phenomena, which are connected with photochemical, plasmic and thermochemical processes [3, 6-8]. It may be various processes, including the cascade and circle processes. Irreversible changes of laser-irradiated volume of matter must be explained as phase transformations. These processes have shock nature and connected with multiphoton scattering processes.

First filaments were observed in 1965 after $20 \mathrm{MW}$ nanopulse laser irradiation of organic liquid [1=3]. These processes are connected with self-focusing processes. Selffocusing of light radiation in air is observed for the convergent and collimated beams.

Later focusing and self-focusing and laser-induced filaments were received in various media: solid $[4,5,9]$, Liquid [10] and gases [11].

The basic results are explained with point of view of transformation of initial radiation in other types of radiation. It is essentially nonlinear optical processes. But trace of finished result of this interaction is little-studied. Therefore, the basic object of this paper is presentation the problem of volume destruction of matter with point of Relaxed Optics.
The nature of optical breakdown is one of discussed problem of modern Nonlinear and Relaxed Optics [1, 7, 12, 13]. According to [13] three types of models may be selected: thermal, plasma and directed optical. First two are characterized of isotropic distribution of continuum radiation $[2,7]$, third - directed distribution of continuum radiation (laser-induced Cherenkov radiation) [3, 13-18].

\section{Experimental data}

Now we represent principal experimental data, which allow determine main peculiarities of laser-induced generation of filaments.

Two damages region in a crystal with moderately high density of inclusions were received in [9] for $\mathrm{KCl}$ after irradiation by $\mathrm{CO}_{2}$-laser pulses (wavelength $10,6 \mu \mathrm{m}$, duration of pulse $30 \mathrm{~ns}$ ). These results are presented in Fig. 1. These data are shown some peculiarities of the optical breakdown in solid. According to [9] two type damages were marked in Fig. 1 [9]. It was found that most of the crystals suffered some damage even at relatively low power levels. The threshold for this type of damages is varied by an order of magnitude from one position in the crystal to other. At any particular energy level, damage would occur on the first laser shot or not at all. Spatial inhomogeneities rather than statistical fluctuations are therefore responsible. Fig, 1(a) shows that these spatial inhomogeneities are in fact inclusions. The damages bubbles occue randomly near, not necessary in, the tiny 
focal volume. At a wild-defined power threshold, an alongated pointed bubble forms, its vertex falling at the focus. (Fig. 2(b)). This power level is regarded as the bulk intrinsic breakdown threshold. Its value is reproducible in crystal from different manufacturers, with inclusions or without. When no inclusion-free samples of a compound were available, the considerations mentioned above were used to determine the dielectric strength [9].

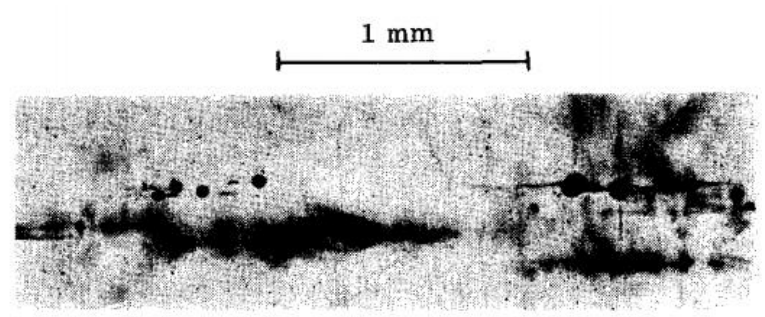

(a)

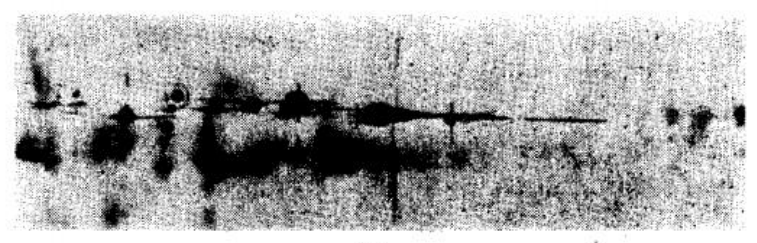

(b)

Fig. 1. Two damages region in a crystal $\mathrm{KCl}$ with moderately high density of inclusions. The round black objects are bubbles. The radiation, incident from left to right, was yust at the intrinsic breakdown threshold. In one case (a) there was damage only at the inclusions. In (b), intribsiv breakdown occurred as evidenced by the pointed bubble. The straight lines represent cleavage [9].

Dynamics of behavior the laser-induced filaments in water was received in '[10]. Refractive index map for two times, which was measured in [10], is represented on Fig. 2. The experiment was carried out of amplified Ti:sapphire laser system (Spectra Physics) delivering wavelength $800 \mathrm{~nm}$, pulse duration $130 \mathrm{fs}$ and rate of pulse repetition $1 \mathrm{kHz}$ [Min]. A spatially filtered laser pulse focused (beam waist diameter was equaled $109 \mu \mathrm{m}$ ) on the front surface of a 20 $\mathrm{mm}$ long fused silica cuvette filled the deionized water to generate the filament of several milimeters.For a pulse energy $4 \pm 0,25 \mu J$, the nonlinear focus was located at $\sim 9,1 \mathrm{~mm}$ beyond the input window of the cuvette. The changes in the reffractive index induce were proved transversally by the filament by $\lambda=560 \mathrm{~nm}, 23 \mathrm{fs}$ long (FWHM), spatially filtered pulses from a noncolinear optical parametric amplifier pumped by the second harmonic of laser. The probe pulses were delayed by a motorized time slide and negatively prechirped to compensate for the dispersion due to cuvette window and the propagation in water untill the plasma channel $(2,5$ $\mathrm{mm})$ [10].

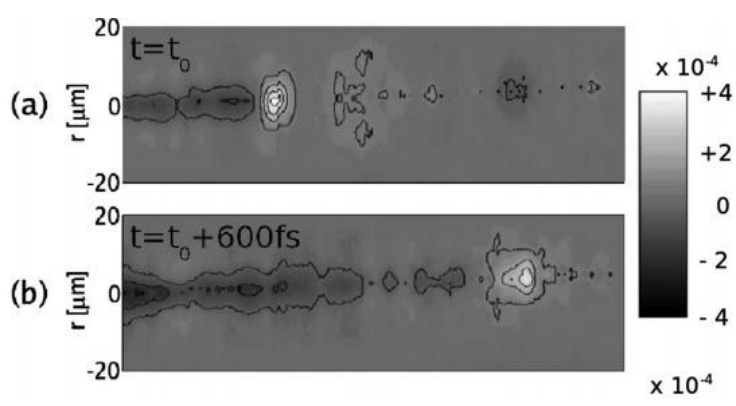

Fig. 2. (a) and (b). Refractive index map of the filament taken at two different times and showing the formation of the plasma channel. Horizontal scale: propagation axis ranging from $9,41 \mathrm{~mm}$ (left) to $9,68 \mathrm{~mm}$ (right) from the input window [10].

The laser-induced filamentation were received in air after irradiation by femtosecond laser pulses (wavelength $800 \mathrm{~nm}$, pulse duration $85 \mathrm{fs}$, energy $230 \mathrm{~mJ}$ and peak power $2,3 T W$, i.e. about 700 critical powers according to [11]) (Fig. 3).

A ring-shape zone supports major spots initiated by the highest intense defects of the initial beam (depth $z=30 \mathrm{~m}$ ). These "hot" spots self-focus more and more over several meters, while they excite secondary smaller-scaled filaments in their vicinity $(z=35 \mathrm{~m})$ [11]. Evacuation of power excess undergone by the primary filaments finally allows transfer of power to the central zone of the beam, which serves as an energy reservoir for exciting new sequences of small spots $(z=50 \mathrm{~m})$ (Fig. 3). Numerical data were represented for duration of pulse $85 f s$ and power few terawatt [11]. From these results specific geometrical zones in the beam pattern were selected [11].

Characteristics examples are indicated by labels 1-3 [11]:

(1) points to a couple of hot couples surviving at further distances;

(2) indicates in active region of the beam, where intense filaments decay into cell of lesser intensity;

(3) identifies an area including a cross-wise structure that keeps some filaments robust over $5 \mathrm{~m}$.

Condition of receiving self-focusing is next: selffocusing must be more as diffraction [2, 4]. Roughly speaking maxima of diffraction pattern may be represented as traces of optical breakdown.

In $[4,5]$ for minituarization of receiving structures of crystals $4 \mathrm{H}-\mathrm{SiC}$ were irradiated by pulses of femtosecond laser (duration of pulses $130 \mathrm{fs}$, wavelength $800 \mathrm{~nm}$, frequency of pulses $1 \mathrm{kHz}$, density of energy 200-300 $n J /$ pulse) with help microscope. 

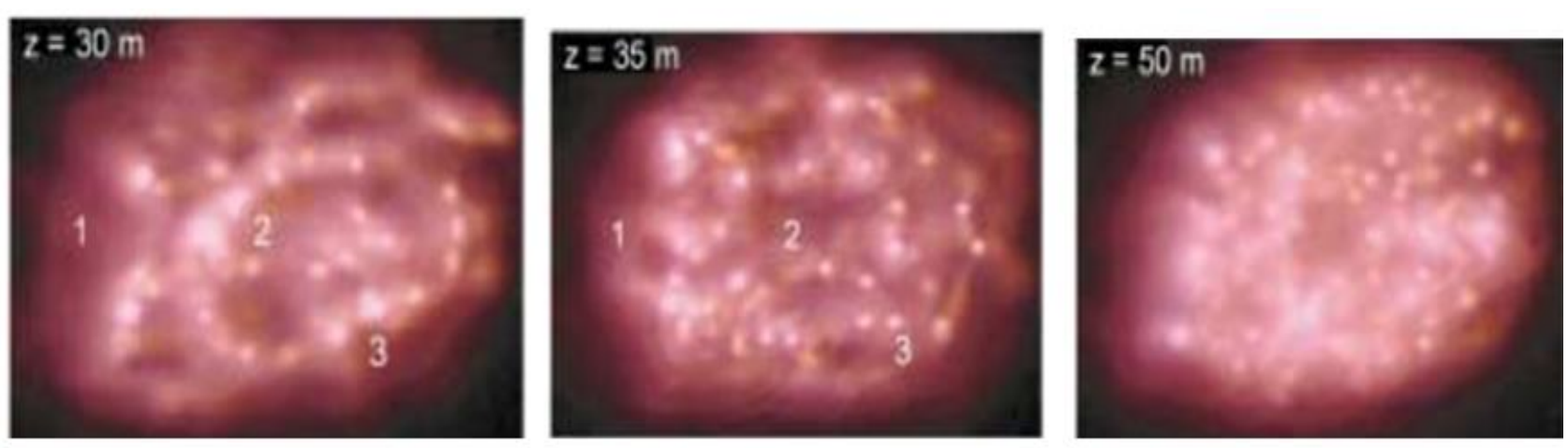

Fig. 3. Filamentation pattern of the $700 P_{c r}$ beam delivered by Teramobile laser. Labels 1-3 spot specific beam zones commented on in the text [11].

Conditions of irradiation are represented in Fig. 4 ((a), (b)) [4]. Femtosecond laser pulses were irradiated along the lines inside $4 \mathrm{H}-\mathrm{SiC}$ single crystals at a depth of $30 \mu \mathrm{m}$ by moving the sample at a scan speed of $10 \mu \mathrm{m} / \mathrm{s}$. The laser beam was irradiated at a right angle to the (0001) surface of the crystal. The irradiated lines were almost parallel to the $[1 \overline{1} 00]$ direction. A schematic illustration of the laserirradiated pattern is shown in Fig. 4 (a). The distance between neighboring lines was $20 \mu \mathrm{m}$.

Bright-field TEM (transmission electron microscopy) image of the cross section of a line written with a pulse energy of $300 \mathrm{~nJ} /$ pulse is shown on Fig. 4 ((c) - (e)) [5].

In this case diffraction processes may be generated in two stages: 1 - formation of diffraction rings of focused beams $[3,17,18]$ and second - formation of diffracting gratings in the time of redistribution of second-order Cherenkov radiatgion $[3,17,18]$. Second case is analogous to the creation of self-diffraction gratings in NLO, but for Fig. 4 (c) and Fig. 4 (g) our gratings are limited by Much cone of Cherenkov radiation.

\section{Modeling and discussions}

The first laser-induced filaments were received in the liquid. Later researches shown that analogous phenomena are generated in solid and gas matter too. Therefore, first models were created for the nonlinear Kerr media and were used for all types of irradiated matter.

If the beam diameter is $D$, the beam might be expected to expand by diffraction with an angular divergence of

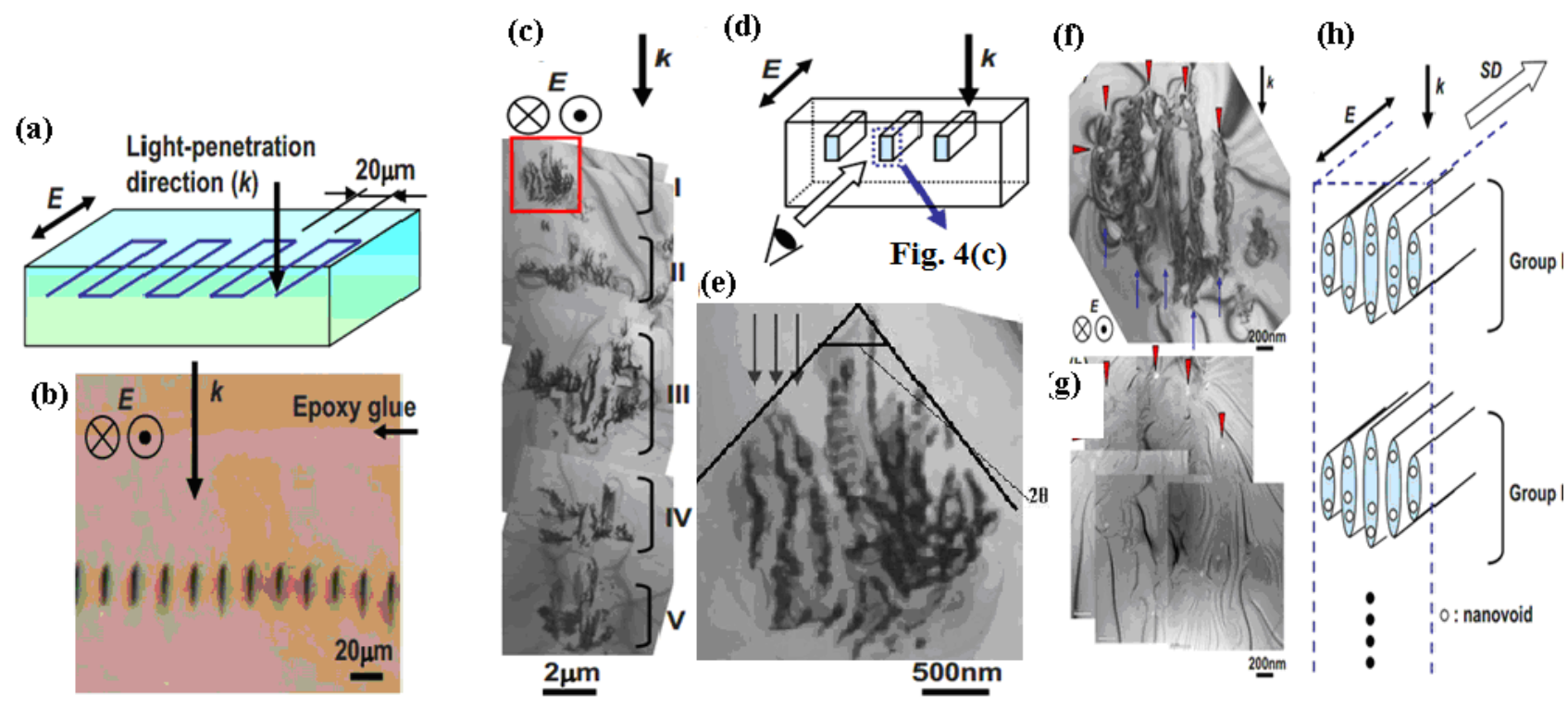

Fig. 4. - (a) Schematic illustration of the laser irradiated pattern. The light propagation direction (k) and electric field (E) are shown. (b) Optical micrograph of the mechanically thinned sample to show cross sections of laser-irradiated lines (200 nJ/pulse). (c) Bright-field TEM image of the cross section of a line written with pulse energy of $300 \mathrm{~nJ} / \mathrm{pulse}$. (d) Schematic illustration of a geometric relationship between the irradiated line and the cross-sectional micrograph. (e) Magnified image of a rectangular area in (c). Laser-modified layers with a spacing of $150 \mathrm{~nm}$ are indicated by arrows. (f) Bright-field TEM image of a portion of the cross section of a line written with a pulse energy of $200 \mathrm{~nJ} / p u l s e$. (g) Zero-loss image of a same area as in (f) with nanovoids appearing as bright areas. Correspondence with (f) is found by noting the arrowheads in both micrographs. (h) Schematic illustrations of the microstructure of a laser modified line. Light-propagation direction (k), electric field (E), and scan direction (SD) are shown. Only two groups (groups I and II) of the laser-modified microstructure are drawn $[4,5]$. 
$\theta=1,22 \lambda / n_{0} D$, where $n_{0}-$ linear refractive index of medium, $\lambda$ - laser wavelength. Therefore, Kerr media critical power may be determined as $[1,2]$

$$
P_{c r}=(1.22 \lambda)^{2} \frac{c}{64 n_{2}}
$$

Where $n_{2}$ is nonlinear refractive index of the medium.

The self-focusing length determined with help next formula [2]

$$
Z_{s f}=\frac{0.367 k \omega_{0}^{2}}{\left[\left(\sqrt{P / P_{c r}}-0,852\right)^{2}-0,0219\right]^{1 / 2}},
$$

Where $k=2 \pi / \lambda$ is the wave number, $\omega_{0}-$ is the spot side of the pump beam, $P$ - pump power.

This formula are using as basic for the determination of threshold self-focusing and self-trapping generation. But this formula can't be use for the determination threshold of power the optical breakdown. For example, the power of creation the laser filaments in irradiated matter may be $\sim 700 P_{c r}[2]$.

In [2] formula for the determination $P_{c r}$, as threshold power of self-focusing, is represented in next form

$$
P_{c r}=\frac{3.77 \lambda^{2}}{8 \pi n_{0} n_{2}} .
$$

Therefore, first model was connected with selffocusing and self-trapping and liquid and other isotropic matter $[1,2]$.

For Kerr media the chande of refractive index is represented as $\delta n=K|E|^{2}$, where $E$ is peak amplitude of linearly polarized field. According to [2, 3] coefficient $K$ may be have 12 presentations.

The explanation of creation the laser-induced filaments have various interpretation. Firstly, it is the creation waveguide zones after point of collapse [2]. In this case filaments have little lifetime.

Conic part of filament radiation has continuum spectrum: from ultraviolet to infrared. Therefore, it may be interpreted as laser-induced Cherenkov radiation $[3,6,14$, 17, 18]. The stratification of this radiation on other types radiation (volume, pseudo-Cherenkov a.o.) has relative character and may be represented as laser-induced Cherenkov radiation [2, 3, 14]. Therefore in future we' 11 be represent conical part of filament radiation as Cherenkov.
This fact may be certified with macroscopic and microscopic ways $[3,13,18]$.

First, macroscopic may be represented according to [3, 14]. Speed of particle, which is generated Cherenkov radiation, must be changed on the speed of laser-induced nonlinear polarization (Fig. 5 b)). The similarity between charge particle and light-induced Cherenkov radiation one can invoke the analogy between Snell's law and Cherenkov radiation too [14]. This natural since both effects can be derived in the same way from the Huygens interference principle. In Fig. 5(a) the point of intersection of a light pulse impinging at an angle $\varphi$ on a boundary between two media moves with velocity $V=C / n_{1} \cos \varphi$. This relation with Snell's law, gives the Cherenkov relation (Fig. 5(b)) [14].

$$
\cos \theta=C / n_{2}(\omega) V
$$

where $n_{2}(\omega)$ is nonlinear refractive index for Fig. $5 \mathrm{~b}$ ) and $n_{2}$ is refractive index of second media for Fig. 5 a) [14].

This formula allows explain the angle differences for various type of Cherenkov radiation [14].

Thus, the refraction law a light at the boundary between two media is the same as the condition for Cherenkov radiation by a source moving along the boundary. In nonlinear medium the emitted frequencies may differ from the excitation frequency. The Cherenkov relation is still valid since the constructive interference occurs at a given Cherenkov angle for each Fourier frequency component of the light-induced nonlinear polarization. In a sense, one can speak about a nonlinear Snell-Cherenkov effect [14].

The Cherenkov angle can also be derived from the conservation of the longitudinal component of the linear momentum at a boundary between two media along which a nonlinear polarization is propagating (Fig. 5((b)). Using $k=\omega / V$, we obtain [14]

$$
\begin{aligned}
& \cos \theta=k_{n l p o l}(\omega) / k_{e m}(\omega)= \\
& =V_{e m} / V_{n l p o l}=C / n_{2}(\omega) V_{n l p o l} .
\end{aligned}
$$

The role of the boundary can be played by the surface of self-trapped filament. The nonlinear polarization propagating along this surface will result in a light-induced Cherenkov $\cos \theta=C / n_{2}(\omega) V$. The nonconservation of the transverse component of the linear momentum can be related to the uncertainty principle, $\Delta x \Delta k>1$, where $\Delta x$ is the thickness of the boundary [14]. 


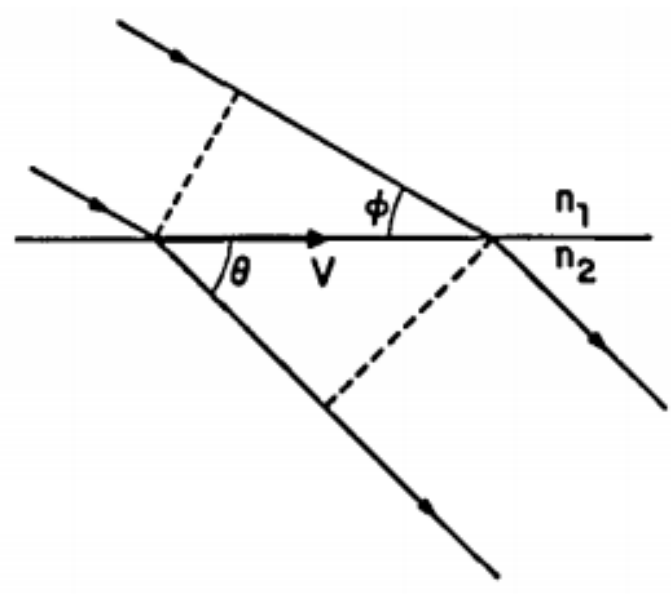

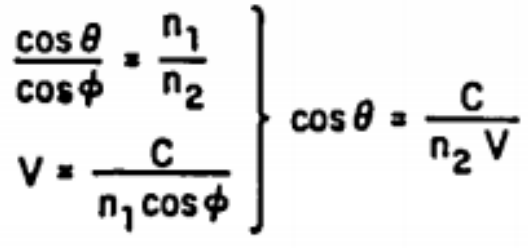

(a)
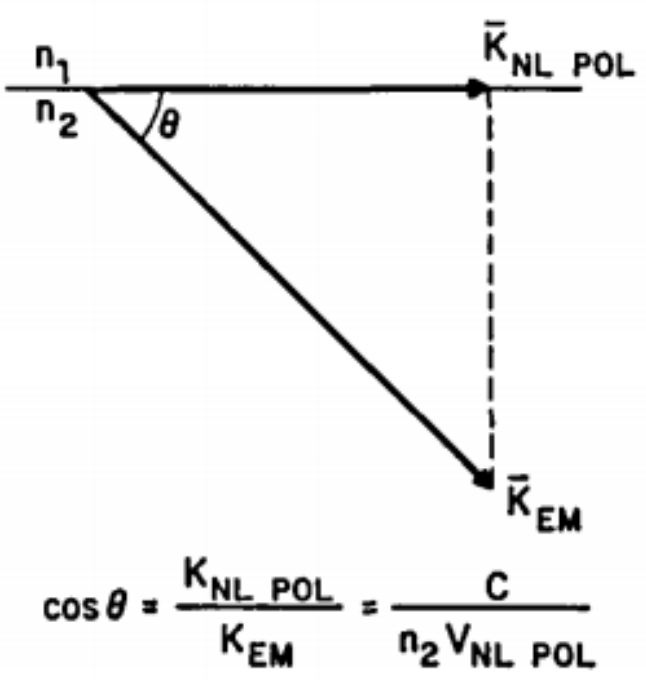

(b)

Fig. 5. [14]. (a) Analogy between Snell's law and Cherenkov radiation. The point of intersection of a light pulse impinging upon a boundary two media moves with velocity $V=C / \cos \varphi$. Combining this relation with Snell's law one obtains the Cherenkov

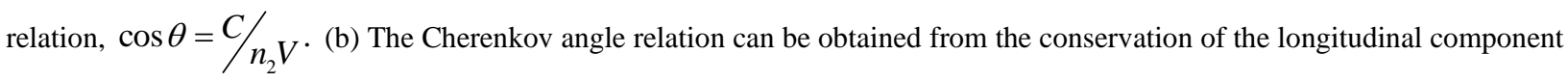
of a linear momentum at a boundary between to media along which a nonlinear polarization is propagated.

The microscopic mechanism of laser-induced Cherenkov radiation is expansion and application of Niels and Aage Bohrs microscopic theory of Cherenkov radiation as part of deceleration radiation on optical case [16]. For optical case the Bohrs hyperboloid must be changed on Gaussian distribution of light for mode TEM $_{00}$ or distribution for focused light of laser beam [3, 6, 13]. In this case Cherenkov angle may be determined from next formula $[3,13]$

$$
\theta_{C h}+\alpha_{i r}=\pi / 2 \text { or } \theta_{C h}=\pi / 2-\alpha_{i r}
$$

where $\alpha_{i r}$ - angle between tangent line and direction of laser beam.

Angle $\alpha_{i r}$ was determined from next formula [3, 13]

$$
\tan \alpha_{i r}=d_{b} / l_{s f}
$$

where $d_{b}$ - diameter of laser beam $(7 \mathrm{~mm}), l_{s f}-$ length of self-focusing. In our case $\alpha_{i r}$ is angle of self-focusing.

This formula is approximate for average angle $\alpha_{i r}$.
The Golub formula (5) was used for the determination product $n_{2}(\omega) V_{n l p o l}[3,13]$. Self-focusing and Cherenkov angles and product $n_{2}(\omega) V$ were estimated for $\mathrm{LiF}, \mathrm{CaF}_{2}$, fused silica, water and glass $B K-7$ in [3].

Thereby microscopic modified Bohrs theory and macroscopic Golub model are mutually complementary methods $[3,13]$.

The decreasing of Cherenkov angle and product $n_{2}(\omega) V$ for increasing of laser radiation intensity are corresponded to increasing of nonlinear refractive index and decreasing of velocity of polarization (multiphotonic and multiwave processes).

The estimation of sizes the cascade of volume destructions of Fig. 4 (c) maybe explains in next way [3, 13]. The sizes (diameters) of proper stages $d_{n i r}$ of cascade are proportionally to corresponding diffraction diameters $d_{\text {ndif }}$

$$
d_{\text {nir }}=\kappa d_{\text {ndif }}
$$

where $\kappa$ is the proportionality constant. 
The diffraction diameters $d_{\text {ndif }}$ may be determined with help condition of diffraction-pattern lobes (modified Rayleygh ratio) $[3,13,17,18]$

$$
d_{n d i f}=n \lambda
$$

The estimations of diffraction diameters $d_{\text {ndif }}$ for $\lambda=$ $800 \mathrm{~nm}$ are represented in Table 1.

Table 1 [32].

\begin{tabular}{|c|c|c|c|c|c|}
\hline$n$ & 1 & 2 & 3 & 4 & 5 \\
\hline $\begin{array}{c}d_{\text {ndif }}, \\
n m\end{array}$ & 800 & 1600 & 2400 & 3200 & 4000 \\
\hline
\end{tabular}

The data of Table 1 for $n=1,2,3$ allow to explain of sizes the first three stages of cascade the volume destruction (Fig. 4 (c)). For this case coefficient $\kappa \sim 2$. But for stages 4 and 5 of Fig. 4 (c) our estimations $\kappa_{4} \sim 1,2$ and $\kappa_{5}=1$. Various values of coefficients $\kappa_{i}$ are explained of various conditions of optical breakdown and creation proper phase transformations.

The distance between diffraction spots and proper moving foci may be determined with help next formula [3, 13]

$$
l_{n f}=\frac{d_{n d i f}}{2 \tan \varphi / 2} .
$$

These distances for $\varphi_{1}=20^{\circ}$ and $\varphi_{2}=30^{\circ}$ are

\begin{tabular}{|c|c|c|c|c|c|}
\hline$n$ & 1 & 2 & 3 & 4 & 5 \\
\hline $\begin{array}{c}l_{n f}, \\
n m \\
\text { for } \varphi_{1} \\
=20^{\circ}\end{array}$ & 2269 & 4538 & 6807 & 9076 & 11345 \\
\hline $\begin{array}{c}l_{n f}, \\
n m \\
\text { for } \varphi_{2} \\
=30^{\circ}\end{array}$ & 1493 & 2985 & 4478 & 5970 & 7463 \\
\hline
\end{tabular}
represented in Table 2.

The conclusion about diffractive stratification of focused radiation may be certified by experimental data of Fig. 4(c).

These results are corresponded to Lugovoy-Prokhorov theory too: distance between contiguous elements is smaller than distance between microscopy ocular and first stage of cascade (correlation of this distance is proportional to $\lambda / d$ ) but distance between contiguous elements of cascade is equal and proportional to half wavelength [3].

Qualitative explanation of development of cascade the destructions may be next $[3,13,18]$. The focus of each diffraction zone (spot) is the founder of proper shock optical breakdown. But foci with more high number may placed in the "zone" of influence of previous foci. Therefore, only first stage of Fig. 4(c) is represented the pure shock mechanism (Mach cone). Mach cones are characterized the second and third stages of Fig. 4 (c). But its maximums are displaced from center. It may be result if interaction second and third shock waves with previous shock waves: first - for second wave and first and second - for third wave. The chock mechanism of destruction certifies a linear direction of optical breakdown. This direction is parallel to direction of shock wave and radiated spectrum is continuous both for Cherenkov radiation and for the observed laser-induced filaments in water and air $[3,13]$. Thus, basic creator of optical breakdown traces is secondary Cherenkov radiation and shock waves. This radiation is absorbed more effectively as laser radiation and therefore the creation of optical breakdown traces is more effectively as for beginning laser radiation. Cherenkov radiation is laid in self-absorption range of $4 \mathrm{H}-\mathrm{SiC}$, but 800 $\mathrm{nm}$ radiation - in intrinsic range. For the testing of this hypothesis we must measure the spectrum of secondary radiation. In this case we can use physical-chemical cascade model of excitation the proper chemical bonds of irradiated matter in the regime of saturation the excitation.

We can rough estimate basic peculiarities of energy distribution in Mach cone may be used next formula [3, 13]

$$
E_{1 o b}=\frac{\pi^{2}}{4}\left(\sum_{i=1}^{5} n_{i a v}^{2} l_{i a v}\right) r^{2} N_{a S i C} E_{Z t h}
$$

where $n_{i a v}-$ average visible number of filaments in proper group of cascade, $l_{i a v}=1000 \mathrm{~nm}$ - average length of filaments in proper group of cascade, $r=10 \mathrm{~nm}$ - average radius of filament, $N_{a}$ - atom density of $4 \mathrm{H}-\mathrm{SiC}, E_{Z t h} \sim 25$ $e V-$ Zeitz threshold energy for $4 \mathrm{H}-\mathrm{SiC}$.

The atom density of $4 \mathrm{H}-\mathrm{SiC}$ may be determined with help next formula $[3,13]$

$$
N_{a}=\frac{n \rho N_{A}}{A},
$$

where $\rho-$ density of semiconductor, $N_{A}-$ Avogadro number, $A$ - a weight of one gram-molecule, $n$ - number of atoms in molecule. For $4 \mathrm{H}-\mathrm{SiC} N_{a S i C}=9,4 \cdot 10^{21} \mathrm{~cm}^{-3}$.

For further estimation we use next approximation $n_{1 a v}=n_{2 a v}=n_{3 a v}=n_{4 a v}=n_{5 a v}=100$, (see Fig. 4(c)). 
Energy, which is necessary for the optical breakdown our nanotubes may be determined in next way. Zeitz threshold energy for $4 \mathrm{H}-\mathrm{SiC}$ is equaled $E_{Z t h} \sim 25 \mathrm{eV}[3,13]$. Let this value is corresponded to energy of optical breakdown. Therefore, summary energy $E_{1 o b}$ is equaled

$$
E_{1 o b}=N_{a s n t} \cdot E_{Z t h}=23,2 n J
$$

This value is equaled of $\sim 8 \%$ from pulse energy or $30 \%$ from the effective absorbed energy of pulse. In this case we have more high efficiency of transformation initial radiation to "irreversible" part of Cherenkov radiation. It is result of more intensive excitation comparatively with classical methods of receiving the Cherenkov radiation. In this case we have pure photochemical processes. The experimental data for intrinsic absorption (Fig. 4) show that for short pulse regime of irradiation (femtosecond regime) basic processes of destruction the fused silica and calcium fluoride are photochemical (multiphoton absorption in the regime of saturation the excitation). But basic peculiarity of experimental data Fig. 5 is transformation the initial laser radiation (wavelength 800 $\mathrm{nm}$ ) to continuum Cherenkov radiation. From length of optical breakdown in $4 \mathrm{H}-\mathrm{SiC}$ we can determine average absorption index of Cherenkov radiation. It is $\sim 10^{4} \mathrm{~cm}^{-1}$. This value is corresponded to violet-blue range of absorption spectrum of $4 \mathrm{H}-\mathrm{SiC}[3,13]$.

We can estimate chain of critical value of energy for the $\mathrm{SiC}$ from physical-chemical point of view too [3, 13].

Critical value of energy, which is necessary for the beginning of self-focusing, may be determined in next way. Volume density of energy of the creation self-focusing process may be represented with help next formula

$$
W_{c r v o l}=E_{a} N_{n c}
$$

where $E_{a}$ - energy of activation proper "nonlinear" centers; $N_{n c}$ - their concentration. In further we made next approximation:

$$
E_{a}=h v=1,5 \mathrm{eV}
$$
$N_{n c}=\left(10^{14}-10^{16}\right) \mathrm{cm}^{-3}$. Then we have for $\mathrm{SiC}$ $W_{\text {crvol }}=2,4 \cdot\left(10^{-5}-10^{-3}\right) \mathrm{J} / \mathrm{cm}^{3}$. 'Surface density for optical thin may be determined as

$$
W_{c r s u r}=W_{c r v o l} / \alpha
$$

where $\alpha$-absorbance index. For $\operatorname{SiC} \alpha=0,1 \mathrm{~cm}^{-1}$. And $W_{\text {crsur }}=2,4 \cdot\left(10^{-4}-10^{-2}\right) \mathrm{J} / \mathrm{cm}^{2}$. Integral value of energy may be determined as

$$
W_{c r i n}=W_{c r s u r} \cdot S
$$

where $S$ - the square of irradiation.

For Fig. 4(c) for $r=2 \mu \mathrm{m}, S=1,256 \cdot 10^{-7} \mathrm{~cm}^{2}$. Therefore $W_{\text {crin }}=3\left(10^{-11}-10^{-9}\right) \mathrm{J}$. For $r=1 \mathrm{~mm}$ we have $W_{\text {crin }}=1,9\left(10^{-6}-10^{-4}\right) \mathrm{J}$. These estimations are corresponded to estimations, which are received with help formulas (1), (3) and other, similar to its [2, 3], electrodynamic formulas.

Next step of determination the density of energy in our cascade is condition of diffractive stratification. This condition may be determined with help of sizes the diffractive rings. We can estimate density of energy in plane of creation the diffractive stratification for $n=5$.

Maximum diameter of diffractive pattern is determined for fifth diffractive ring. For this case average density of energy in plane of diffractive rings is equaled

$$
W_{a v d r}=E_{p} / S
$$

Where $E_{p}$ - energy of laser pulse. For $E_{p}=200 n J$ and $E_{p}$ $=300 \mathrm{~nJ}$ and $S=1,256 \cdot 10^{-7} \mathrm{~cm}^{2}$ we have next value of $W_{a v d r}$ $1,6 \mathrm{~J} / \mathrm{cm}^{2}$ and $2,4 \mathrm{~J} / \mathrm{cm}^{2}$. If we multiple this value of the absorbance index of $\mathrm{SiC} \alpha=0,1 \mathrm{~cm}^{-1}$ then we are receiving the volume density of energy $W_{\text {avdrvol }} 0,16 \mathrm{~J} / \mathrm{cm}^{3}$ and 0,24 $\mathrm{J} / \mathrm{cm}^{3}$. Really value is 0,4 from represented data (reflectance is 0,6) and are 0,064 and 0,096 J/ $\mathrm{cm}^{3}$

Correlation $W_{\text {avdrvol }} / W_{\text {crvol }}$ for real values for $\mathrm{SiC}$ is equaled from 27 to 2700 .

Density of energy of optical breakdown $W_{o b}$ for $\mathrm{SiC}$ is equaled $48000 \mathrm{~J} / \mathrm{cm}^{3}$. Therefore correlation $W_{o b} / W_{\text {avdrvol }}$ is equaled $5 \cdot 10^{5}$ and $7,5 \cdot 10^{5}$.

Analogous physical-chemical estimations may be made for the data of Fig. 1 - Fig. 3.

The questions about supercontinuum radiation in the process of femtosecond laser filamentation are discussed in $[1-3,13,14]$. In air supercontinuum spectra laid from ultraviolet to infrared ranges of spectra. In whole nonlinear optics of filaments is included the superexpansion of frequency-angle spectrum of initial pulse, generation of more higher harmonics and terahertz irradiation, pulse compression, optical anisotropy of filament and other nonlinear phenomena [1-3. 13, 14].

In whole microscopic mechanism of laser-induced Cherenkov radiation may be represented as nonequilibrium spectrum of all possible Nonlinear Optical phenomena in the local points of propagation the laser beam. It may be Raman and Brillouin scattering, up- and down-conversion, generation of harmonics and various interference of these processes and phenomena, which are generated the continuous spectrum from ultraviolet to infrared regions $[2,3,7,12]$. 
Cherenkov radiation with optical pumping may be represented as Nonlinear Optical process with speed, which is less as light phase speed in irradiated matter. In this case phase speed in matter has physical nature: it is the electromagnetic speed of "collective" motion the charge particles or charges in matter. Therefore, in local scale we have Nonlinear Optical processes, which are modulated of the Mach cone the Cherenkov radiation (Fig. 4 (c)). It allow to add the Niels and Aage Bohrs theory [16] about microscopic mechanism of Cherenkov radiation $[15,16]$.

In solid this spectrum must be displaced to ultraviolet range. Therefore, our traces of filaments have more short lengths as in water or air [1-3, 13]. Basic cause of this fact is more density of solid and more intensive light absorption. But in the liquid and air the direct optical breakdown is realized and these types of matter have more "soft" relaxation as solid. And processes of multiphoton ionization in the regime of self-focusing are more slowly as in solid. Continuum spectrum of filaments in this case is corresponded to the renewal disrupting chemical bonds and electronic states of irradiated molecules and atoms.

Experimental data of Fig. 1 - Fig. 4 may be explain on the basis the two-dimensional interference of various waves or V. Makin polariton-plasmon model [8]. Maxima of these interferograms are sources of more intensive ionization of irradiated matter and concomitant processes of phase transformations (Fig. 1 - Fig. 4) or radiation (Fig. 3).

As we see sources of Relaxed Optical processes are Optical and Nonlinear Optical processes and phenomena [3. 6].

Concept of diffractive stratification allows explaining the surface character of Cherenkov radiation. This radiation is generated in the region of proper focused diffractive ring [3, 14].

Rayleygh model is basis on resolution of Besant problem [3], which is formulated in next form "An infinite mass of homogeneous incompressible fluid acted upon by no forces is at rest, and a spherical portion of the fluid is suddenly annihilated; it is required to find the instantaneous alteration of pressure at any point of the mass, and the time in which the cavity will be fill up, the pressure at a infinite distance being supposed to remain constant.

Rayleygh received resolution this problem for the sound shock processes for liquid. In this case cavitations' bubbles have sizes from a few millimeters to a few centimeters [3].

In our case (Fig. 4 (h)) sizes of our nanovoids are equaled $15-20 \mathrm{~nm}$. Therefore, we must change "sound" mechanism of creation cavitations bubbles on electromagnetic. This problem was resolved with help change velocity of sound on velocity of light $[3,13,17$, $18]$.
The sizes of nanovoids (Fig. 4(h)) may be determined with help modified Rayleygh model [3, 13, 17, 18] and its form - the help methods of continuum mechanics [3] in next way.

Nanovoids may be represented as results of the laserinduced laser-induce breakdown and creation of cavitations bubbles $[3,13,17,18]$ too. The light pressure may be determined with help of next formula $[3,13,17$, 18]

$$
p_{0}=\frac{E_{i r}}{\tau_{i} c S},
$$

where $E$ - energy of irradiation, $\tau_{i}$ - pulse duration, $S$ - area of irradiation zone, $c$ - speed of light. For circle symmetry

$$
S=\pi r^{2}
$$

where $r$ - radius of laser spot.

For the estimations of maximal radius of nanovoids we must use modified Rayleygh formula [3, 13, 17, 18]

$$
R_{\max } \simeq \frac{2 R}{0,915 r} \sqrt{\frac{E_{i r}}{\pi \tau_{i} c E}} .
$$

where $R$ is radius of nanovoid (bubble), $r$ - radius of irradiated zone, $E$ - Young module, $E_{i r}$ - energy of one pulse. $\tau_{i}$ - duration of pulse $[4,6]$.

If we substitute $r=250 \mathrm{~nm}, R=10 \mathrm{~nm}, E=600 \mathrm{GPa}$ [4, 6], $E_{i r}=130 \mathrm{~nJ}, \tau_{i}=130 \mathrm{ps}, c=3 \cdot 10^{8} \mathrm{~m} / \mathrm{s}$ in (20), then we have $R_{\max }=11 \mathrm{~nm}$.

We can introduce two speeds of sound in elastic body: longitudinal $\vartheta_{l s}$ and transversal $\vartheta_{t s}$ [3]. Its values are determined with next formulas

$$
\vartheta_{l s}=\sqrt{\frac{E(1-v)}{\rho_{o}(1+v)(1-2 v)}},
$$

and

$$
\vartheta_{t s}=\sqrt{\frac{E}{2 \rho_{o}(1+v)}},
$$

where $v$ - Poisson's ratio [3]. The ratio between of these two speeds is equaled

$$
\alpha=\frac{\vartheta_{t s}}{\vartheta_{l s}}=\sqrt{\frac{(1-2 v)}{2(1-v)}} .
$$

But this ratio must be true for shock waves too. Therefore, for silicon carbide for $v=0,45$ [3] $\alpha=0,33$. 
Roughly speaking last ratio is determined the step of ellipsoidal forms of our nanovoids (Fig. 4 (h)).

In $[4,7]$ allow estimating maximal longitudinal and transversal $R_{\max i}, i \in(l, t)$. These values are $6 \mathrm{~nm}$ and 19 $n m$ properly.

In this case we represented $4 \mathrm{H}-\mathrm{SiC}$ as isotropic plastic body. For real picture we must represent hexagonal structure. But for the qualitative explanation of experimental data of Fig. 4 this modified Rayleygh model allow explaining and estimating the sizes and forms of receiving nanovoids.

As we see, for laser-induced breakdown we must include self-focusing processes too. The problem of creation initial inoculating concentration of electrons is one of main problems Nonlinear Optics too. Therefore, we must include in the problem of optical breakdown the heterogeneity materials and heterogeneity of interaction light and matter, including diffraction stratification, generation of continuum radiation (including Cherenkov radiation), interference Cherenkov radiation and direct optical breakdown. These addition factors allow explaining basic peculiarities of interaction laser irradiation and matter, including gases (Fig. 3), liquid (Fig. 2) and solid (Fig. 1 and Fig 4).

But for more long time of irradiation we have secondorder processes of disorder radiation, including reradiation and reabsorption [3]. In this case we may be having processes of heating and creation of plasma clouds [2, 3, 7, 13]. For shorter regimes of irradiation, a probability of cascade step-by-step laser-induced direct multiphotonic excitation is increased and therefore we have third scenario of these processes [13].

Thus, methods of Relaxed Optics allow integrating processes of radiated and nonradiated relaxation (Nonlinear and Relaxed Optics) of first-order optical excitation in one system and allow explaining processes of generation the laser-induced filaments, optical breakdown and shock processes with one point of view. For qualitative explanation of corresponding experimental data we must add using methods by physical-chemical models and methods of diffraction stratification and laser-induced Cherenkov radiation.

\section{Conclusions}

1. The experimental data of creation the laserinduced filaments in various media are discussed.

2. Main theories and model, which are used for the modeling of these data, are analyzed.

3. We show that the processes of generation the laser-induced filaments are connected with processes of diffraction stratification of laser beam; generation of continuum radiation, including Cherenkov radiation; interference of Cherenkov radiation and direct optical breakdown of irradiated matter.

4. Corresponding theories and models allow to explain basic peculiarities of the represented experimental data.

5. Thus, the generation of laser-induced filaments is more complex processes as thermal or plasma breakdown of irradiated matter.

\section{References/Literature}

1. Y.R. Shen. Principles of nonlinear optics. (Nauka, Moscow, 1989), 559 р. (И.Р. Шен. Принциипь нелинейной оптики. (Наука, Москва)) [In Russian]

2. Eds. R.W. Boyd, S.G. Lukishova, Y.R. Shen. Self-Focusing: Past and Present. Springer Series: Topics in Applied Physics. Vol. 114. (Springer Verlag, New York, 2009), $605 \mathrm{p}$.

3. P.P. Trokhimchuck Relaxed Optics: Modeling and Discussions. (Lambert Academic Publishing, Saarbrukken, 2020), 249 p.

4. T. Okada, T. Tomita, S. Matsuo, S. Hashimoto, Y. Ishida, S. Kiyama, T. Takahashi. J. Appl. Phys., 106, 054307 (2009).

5. T. Okada, T. Tomita, S. Matsuo, S. Hashimoto, R. Kashino, T. Ito. Material Science Forum, 725, 19 (2012).

6. P.P. Trokhimchuck. Relaxed Optics: Realities and Perspectives. (Lambert Academic Publishing, Saarbrukken, 2016), $260 \mathrm{p}$.

7. V.P. Veyko, M.N. Libenson, G.G. Chervyakov, E.B. Yakovlev. Interaction laser irradiation and matter. Force optics. (Phyzmatlit, Moscow, 2008), 310p. (В.П. Вейко, М.Н. Либенсон, Г.Г. Червяков, Е.Б. Яковлев. Взаимодействие лазерного излучения и вещества. Силовая оптика. (Физматлит, Москва)) [In Russian]

8. V.S. Makin. Thesis. Saint-Petersburg (2013), 384 p. [In Russian]

9. E. Yablonovich Appl. Phys. Lett., 11, 495 (1971)

10. S. Minardi, A. Gopal, M. Tatarakis, A. Couairon, G. Tamosăuskas, R. Piskarskas, A. Dubietis, P. Di Trapani. Opt. Lett. 33, 1, 86 (2008).

11. L. Berge, S. Skupin, F. Lederer, G. Mejean, J. Yu, J. Kasparian, E. Salmon, J. P. Wolf, M. Rodrigues, L. Wöste, R. Bourayou, R. Saurbrey. Phys. Rev. Lett. 92, 22, 225002 (2004).

12. V. K. Miloslavskiy. Nonlinear Optics. (Karazin University Press, Kharkov, 2008), 312 р. (В.К. Милославский. Нелинейная оптика. (Издательство Каразинского университета, Харьков)) [In Russian]

13. P. P. Trokhimchuck. IJARPS, 7, 5, 17 (2020).

14. I. Golub. Optics Letters, 15, 6, 305 (1990).

15. I.M. Frank. Cherenkov Radiation. Theoretical Aspects, (Nauka, Moscow, 1988), 286p. (И.М. Франк. Черенковское излучение. Теоретические аспекты, (Наука, Москва)) [In Russian]

16. N. Bohr. The passage of charged particles through matter, (IL, Moscow, 1950), 148 p. (Н. Бор. Прохождение заряженных частии через вещество, (ИЛ, Москва)) [In Russian]

17. P. P. Trokhimchuck. IJARPS, 6. 7, 5 (2019).

18. P. P. Trokhimchuck. Proc. CAOL'2019. IEEE publisher, 437, (2020). 